\title{
Hubungan Polimorfisme Gen ACTN-3 (R577X) dengan Daya Ledak Otot pada Siswa Sekolah Sepakbola di Medan
}

\section{Association of ACTN-3 Gen Polymorphism (R577X) and Muscle Explosion in Soccer School Students in Medan}

\author{
Martina Evlyn $\mathrm{RH}^{1,2}$, Amira Permata $\mathrm{ST}^{3}$, Dedi Ardinata ${ }^{4}$ \\ ${ }^{1}$ Akademi Keperawatan RSU Herna Medan \\ ${ }^{2}$ Program Magister Biomedik Fakultas Kedokteran Universitas Sumatera Utara Medan \\ ${ }^{3}$ Departemen Pulmonologi dan Ilmu Kedokteran Respirasi Fakultas Kedokteran Universitas Sumatera Utara Medan \\ ${ }^{4}$ Departemen Fisiologi Fakultas Kedokteran Universitas Sumatera Utara Medan
}

\begin{abstract}
ABSTRAK
Gen ACTN-3 merupakan gen yang mengkode sebuah protein sarkomer yang hampir secara keseluruhan diekspresikan dalam serat otot cepat dan menghasilkan daya ledak otot. Daya ledak (power) adalah kemampuan otot untuk mengatasi tahanan beban dengan kekuatan dan kecepatan tinggi dalam suatu gerakan yang utuh. Daya ledak merupakan komponen penting dalam olahraga sepakbola. Variasi genotif (polimorfisme) ACTN-3 (R/X) cenderung memiliki daya tahan yang lebih baik. Tujuan penelitian ini untuk menganalisis hubungan antara varian genotif ACTN-3 (polimorfisme) dan daya ledak otot. Subjek penelitian ini adalah siswa sekolah sepakbola berusia 11-14 tahun yang berjumlah 33 orang. Daya ledak otot diukur menggunakan tes standing broad jump. Varian genotif (polimorfisme) gen ACTN-3 diidentifikasi menggunakan PCR-RFLP dari sampel sel bukal. Uji Fisher Exact digunakan untuk mengetahui hubungan antara polimorfisme gen ACTN-3 dengan daya ledak otot. Hasil studi menunjukkan varian genotif ACTN-3 yang memiliki alel R cenderung menunjukkan daya ledak otot kategori diatas rata-rata dan tinggi, sementara varian genotif yang memiliki alel $\mathrm{X}$ lebih banyak menunjukkan daya ledak otot dalam tingkat rata-rata. Penelitian ini menunjukkan bahwa secara statistik ada hubungan signifikan antara polimorfisme gen ACTN-3 dengan daya ledak otot pada siswa sekolah sepakbola kota Medan $(p<0,001)$ dengan kekuatan korelasi kuat $(\mathrm{c}=0,623)$.
\end{abstract}

Kata Kunci: ACTN-3, daya ledak otot, polimorfisme, tes standing broad jump

\begin{abstract}
ACTN-3 gene is a gene that encodes a sarcomere protein that is almost expressed entirely in fast muscle fibers and produces muscle explosive power. Power is an ability of the muscles to overcome load resistance with high strength and speed in a complete motion. Explosive power is an important component in soccer. Genotypic variations (polymorphisms) of ACTN-3 $(R / X)$ tend to have a better endurance. The purpose of this study was to analyze the relationship between ACTN3 genotype variant (polymorphism) and muscle explosive power. The subjects of this study were students of football schools aged 11-14 years, as many as 33 people. Muscle explosive power was measured using standing broad jump test. The genotype variant (polymorphism) of ACTN-3 gene was identified using PCR-RFLP from a buccal cell sample. Fisher Exact test was used to determine the relationship between ACTN-3 gene polymorphism and muscle explosive power. The results of the study show that genotypic variant of ACTN-3 which has an $R$ allele tends to show muscle explosive power above the average and high categories, while the genotypic variant that had $X$ alleles show more muscle explosive power on an average level. This study shows that statistically there is a significant relationship between ACTN-3 gene polymorphism and muscle explosive power in soccer school students in Medan $(p<0.001)$ with strong correlation ( $c=0.623)$.
\end{abstract}

Keywords: ACTN-3, muscle explosive power, polymorphism, standing broad jump test

Korespondensi: Martina Evlyn RH. Akademi Keperawatan RSU Herna Medan, Jl. Dr. TD Pardede No 21 Medan Tel. 081361786784, email: tina_hutahaean@yahoo.com

DOI: http://dx.doi.org/10.21776/ub.jkb.2018.030.02.8 


\section{PENDAHULUAN}

Minat masyarakat Indonesia terhadap permainan sepakbola begitu besar, tetapi tidak diimbangi dengan prestasi di dunia persepakbolaan Internasional. Kecepatan (speed), kekuatan (power) dan ketahanan (strength) merupakan komponen penting untuk mencapai perfoma yang baik selama pertandingan (1). Daya ledak (power) adalah kemampuan otot untuk mengatasi tahanan beban dengan kekuatan (strength) dan kecepatan (speed) tinggi dalam suatu gerakan yang utuh (1). Semburan ledakan dibutuhkan karena sepak bola merupakan permainan bola dengan intensitas tinggi yang melibatkan sprint, perubahan arah yang cepat, lompatan dan tendangan. Pemain bola profesional melakukan aktivitas yang berubah-ubah sebanyak 1.2001.400 kali, akumulasi serangan durasi pendek sebanyak 150-250 dengan intensitas tinggi. Penipisan glikogen terjadi akibat dari akselerasi berintensitas tinggi, deselerasi dan sprint selama pertandingan (2). Selain teknik dan keterampilan taktis, pemain sepak bola harus dapat mengembangkan dan mempertahankan kondisi aerobik dan anaerobik yang tinggi, kecepatan, agilitas, kekuatan, dan daya ledak untuk menjadi pemain yang professional $(3,4)$.

Konsep bahwa sifat-sifat genetik sangat terkait dengan perfoma fisik manusia telah diterima secara luas. Pewarisan genetika pada atlet diperkirakan sekitar $66 \%$. Mengetahui profil genetika secara dini dan tepat akan berkontribusi mengembangkan bakat yang dimiliki atlet, sehingga dapat meningkatkan performa dan prestasi atlet $(5,6)$. Peta gen manusia (human map gene) mengidentifikasi lebih dari 200 variasi genetik secara potensial terkait dengan fenotipe perfoma fisik atau pelatihan responsif $(7,8)$.

Salah satu gen yang berhubungan dengan performa elit atlet adalah gen $\alpha$-actinin-3 (ACTN-3), gen yang terletak pada kromosom manusia 11q13.2 terdiri atas 21 ekson. Gen ini mengkode protein sarkomer yang hampir secara keseluruhan diekspresikan dalam serat otot cepat (fast glycolytic/tipe II) yang berperan penting dalam kecepatan dan kontraksi kekuatan otot penuh atau pembangkit daya ledak otot $(7,9)$. Genotif ACTN3 berkaitan dengan kecepatan dan fenotif daya ledak (power) (10-12).

Sekitar $16 \%$ populasi di dunia mengalami polimorfisme pada gen ACTN-3 (fully ACTN-3 deficient) dan hal ini disebabkan oleh polimorfisme prematur stop codon homozigot pada gen ACTN-3 (9). Terjadinya nonsense mutation pada gen ACTN-3 ini, yaitu subtitusi satu basa sitosin (C) menjadi tymin (T) pada posisi 1747 (C1747) ekson ke 16 (kodon CGA menjadi TGA) sehingga membentuk stop codon $(\mathrm{X})$ pada asam amino arginin $(\mathrm{R}) \mathrm{di}$ posisi rantai protein 577 , yang mengakibatkan pembentukan protein yang tidak aktif (13). Individu dengan genotype 577XX tidak memiliki ACTN-3 pada serat otot putih (fast-twitch fibres). Versi basa sitosin (R) menghasilkan gen ACTN-3 yang berfungsi penuh menghasilkan protein alpha actinin dalam jumlah yang banyak. Beberapa penelitian membuktikan bahwa atlet elit sprint secara signifikan memilki frekuensi alel $\mathrm{R}$ yang lebih tinggi (9-11). Versi basa tymin (X) menghasilkan protein ACTN-3 yang non fungsional. Defesiensi protein ACTN-3 ini tidak menunjukkan fenotip penyakit atau gangguan fungsional otot $(7,14,15)$.
Tidak adanya ACTN-3 pada serat otot cepat dikompensasi dengan upregulasi ACTN2 dan enzim lain yang mengambil bagian dalam metabolisme anaerobik (16). Defesiensi ACTN-3 menunjukkan perubahan secara metabolik yaitu peningkatan akivitas enzim glikolisis dan metabolism aerobik serta penurunan aktivitas metabolik enzim anerobik secara maksimal (7). Quinlan (14) menunjukkan terjadinya peningkatan glikogen, peningkatan GS (glycogen synthase) dan penurunan GPh (glycogen phosporylase) pada defisiensi ACTN-3 model tikus dan keadaan ini akan sama dengan manusia. Hal ini disebabkan interaksi GPh dengan ACTN-3. Upregulasi ACTN-2 yang berinteraksi dengan protein di garis $\mathrm{Z}$ menunjukkan perubahan struktural yang menjadi awal perubahan metabolik. Karena ACTN-2, ACTN-3 dan GPh melekat pada garis Z, kehilangan ACTN-3 mengubah konformasi 3 dimensi garis $Z$, yang mengubah ketersediaan GPh untuk fosforilasi dan aktivasi $(9,14)$.

Tujuan penelitian ini untuk mengetahui hubungan antara polimorfisme gen ACTN-3 terhadap daya ledak otot (muscular power) pada siswa sepak bola di Medan.

\section{METODE}

Penelitian ini menggunakan studi cross sectional yang dilakukan di Sekolah Sepak Bola (SSB) Sejati Pratama, SSB Universitas Sumatera Utara dan Laboratorium Terpadu Fakultas Kedokteran Universitas Sumatera Utara (FK USU). Persetujuan etik diperoleh dari komisi etik Fakultas Kedokteran Universitas Sumatera Utara dengan nomor 270/TGL/KEPK FKUSU-RSUP HAM/2017.

\section{Sampel}

Sampel penelitian sebanyak 33 orang, berusia 11-14 tahun, menjalani latihan rutin minimal 3 kali dalam seminggu di Sekolah Sepak Bola, tidak menderita penyakit paru yang dibuktikan dengan hasil spirometri yaitu tidak ada restriksi atau obstruksi.

Sel bukal diambil menggunakan buccal-brush. Isolasi DNA dari sel bukal dilakukan di Laboratorium Terpadu FK USU. Bahan yang digunakan untuk isolasi DNA, antara lain; Proteinase $K(100 \mu \mathrm{g} / \mathrm{mL})$, PrestoTM Buccal Swab gDNA Extraction Kit (Geneaid), 10x Tris-Acetate-EDTA (TAE) Buffer (Vivantis). Untuk mengukur konsentrasi dan kemurnian DNA digunakan Nanophotometer. Primer dari GenBank Sequence Database-NCBI (accession numberNG_013304.2, GenelD: 641451071) yang digunakan untuk amplifikasi adalah primer forward 5 'CTG TTG CCT GTG GTA AGT GGG-3' dan reverse primer 5'TGG TCA CAG TAT GCA GGA GGG-3'. Reaksi PCR terdiri atas forward primer $1,0 \mu \mathrm{L}$, reverse primer $1,0 \mu \mathrm{L}$, GoTaq $(\mathrm{R})$ Green Master Mix (Promega, USA) 12,5 $\mu \mathrm{L}$, sampel DNA 2,0 $\mu \mathrm{L}$ dan Nucleus Free Water 8,5 $\mu \mathrm{L}$ hingga volume $25 \mu \mathrm{L}$. Program PCR yang digunakan adalah denaturasi awal $95^{\circ} \mathrm{C}$ selama 3 menit, denaturasi $95^{\circ} \mathrm{C}$ selama 30 detik, annealing $53^{\circ} \mathrm{C}$ selama 20 detik, extension $72^{\circ} \mathrm{C}$ selama 18 detik, dilakukan sebanyak 35 siklus dan terakhir final extension $72^{\circ} \mathrm{C}$ selama 10 menit. Produk PCR yang didapat sebesar 291bp, kemudian dipotong oleh enzim retriksi Dde1 dengan komposisi sebagai berikut NE 10x Buffer

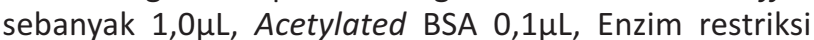
Dde1 0,2 $\mu \mathrm{L}$, Nucleus Free Water $3,7 \mu \mathrm{L}$ dan produk PCR $5,0 \mu \mathrm{L}$, kemudian diinkubasi pada suhu $65^{\circ} \mathrm{C}$ selama 30 menit. Hasil PCR-RFLP kemudian dielektroforesis menggunakan larutan TAE dan gel agarose 4\% dengan 
tegangan sebesar 100 Volt selama 50 menit dan divisualisasi menggunakan pewarnaan etidium bromida.

Pemeriksaan daya ledak otot menggunakan tes Standing Long Jump atau sering disebut dengan tes Standing Broad Jump (17). Jarak lompatan akan dinterpretasikan menjadi daya ledak otot. Interpretasi hasil Standing Broad Jump adalah kategori tinggi (diatas 75 persentil), kategori diatas rata-rata (persentil 50-75), kategori ratarata (persentil (25-50) dan kategori rendah (pers \entil 525) dan kategori sangat rendah (dibawah persentil 10) (17).

Uji statistik yang digunakan untuk mengetahui apakah terdapat hubungan yang signifikan antara varian genotif ACTN-3 dengan daya ledak otot adalah uji analisa statistik Fisher's dan untuk menguji korelasi antara varian genotif ACTN-3 dengan daya ledak otot tungkai digunakan uji korelasi koefisien kontingensi.

\section{HASIL}

Subjek penelitian merupakan siswa sekolah sepakbola (SSB) yang berusia 11-14 tahun, berjenis kelamin laki-laki, melakukan latihan sepak bola secara rutin minimal 3 kali seminggu selama 6 bulan dibimbing oleh pelatih, tidak memiliki riwayat penyakit paru yang dibuktikan oleh hasil spirometri yang menunjukkan tidak terdapat restriksi dan obstruksi.

Tabel 1 menunjukkan bahwa persentase variasi genotif RX terbesar dengan jumlah alel $X(0,61 \%)$ lebih banyak dibandingkan alel $\mathrm{R}(0,39 \%)$.

Tabel 1. Distribusi polimorfisme gen ACTN3, jumlah dan frekuensi alel $\mathrm{R}$ dan $\mathrm{X}$

\begin{tabular}{lcc}
\hline Polimorfisme Gen ACTN-3 & Jumlah & Persentase (\%) \\
\hline RR & 6 & 18,2 \\
RX & 14 & 42,4 \\
XX & 13 & 39,4 \\
Alel R & 26 & 0,39 \\
Alel X & 40 & 0,61 \\
Jumlah Alel R dan X & 66 & \\
\hline
\end{tabular}

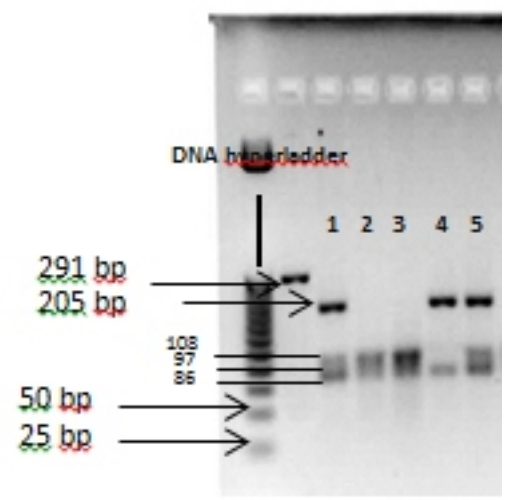

Gambar 1 Hasil Elekroforesis PCR-RFLP produk gen ACTN-3 (Lane 1, 5: RX; Lane 2,3: XX; Lane 4: RR)

Gambar 1 menunjukkan hasil PCR-RFLP diperoleh 3 jenis varian genotif ACTN-3 yaitu RR (2 pita) di Lane IV, RX (4 pita) di Lane I, V, dan XX (3 pita) di Lane II, III.

Tabel 2. Analisa bivariat varian genotif (polimorfisme) ACTN-3 dengan daya ledak otot

\begin{tabular}{cccc}
\hline \multirow{2}{*}{$\begin{array}{c}\text { Genotif } \\
\text { ACTN-3 }\end{array}$} & Tinggi & Daya ledak otot \\
& $\mathbf{n}(\%)$ & Rata-rata/ & $\boldsymbol{p}$ \\
\hline RR & $1(3,03)$ & $5(15,15)$ & \\
RX & $6(18,18)$ & $8(24,24)$ & $* 0,000$ \\
XX & $2(6,06)$ & $11(33,33)$ & \\
\hline
\end{tabular}

Keterangan: *uji Fisher sig<0,05

Hasil pemeriksaan daya ledak otot menunjukkan daya ledak otot anak-anak sekolah sepak bola yaitu daya ledak tinggi sebanyak 9 orang $(27,27 \%)$ dan daya ledak ratarata/diatas rata-rata 24 orang $(72,73 \%)$. Pada penelitian ini tidak dijumpai daya ledak otot rendah dan daya ledak otot sangat rendah. Subjek dengan varian genotif RX yang memiliki daya ledak otot kategori tinggi sebanyak 6 orang $(18,18 \%)$, daya ledak otot kategori rata-rata/diatas ratarata sebanyak 8 orang $(24,24 \%)$. Sementara subjek dengan varian genotif XX memiliki daya ledak otot kategori tinggi sebanyak 2 orang $(6,06 \%)$ dan daya ledak otot kategori diatas rata-rata/rata-rata sebanyak 11 orang (33,33\%). Hasil uji analisa statistik menggunakan uji Fisher's $(p<0,001)$ yang menunjukkan ada hubungan yang signifikan antara varian gen ACTN-3 dengan daya ledak otot. Hasil uji korelasi koefisien kontingensi antara variabel varian gen ACTN-3 dengan daya ledak otot menunjukkan hubungan yang kuat $(0,623)$.

\section{DISKUSI}

Pada penelitian ini, genotif $\mathrm{RX}$ memiliki persentase terbesar $(42,4 \%)$ diikuti genotif XX $(39,39 \%)$ dan RR $(18,2 \%)$. Penelitian lain tentang ACTN-3 di Indonesia juga memperoleh hasil yang sama dengan penelitian ini. Dari hasil penelitian Gumilas et al., didapatkan bahwa RX memiliki persentase 57,1\%, XX; 24,7\% dan RR; $18,2 \%$ ( $n=68)$ (18); penelitian Ambardini (19), varian genotif RX (72,5\%), diikuti RR (14,9\%), dan XX (12,6\%); penelitian Candrawati (20) menunjukkan varian genotif RX; 54,9\%, XX; $26,8 \%$ dan RR; $18,3 \%$ ( $n=82$ ). Pada populasi Polandia, varian genotif $\mathrm{RX}$ menunjukkan persentase yang paling besar (43,75\%) (6). Penelitian Ahmetov (21) pada atlet endurens di Rusia juga menunjukkan genotif RX 55\% sedangkan genotif RR 39,3\% ( $=456)$. Kothari (22), dan Fattahi et al., (23) yang menyatakan bahwa genotif RX ditemukan lebih banyak pada bangsa Asia dibandingkan RR dan XX. Sebaliknya, hasil ini berbeda di Afrika (Kenya, Nigeria dan Afrika Selatan), yang menemukan genotif RR lebih banyak dibandingkan genotif RX dan XX $(7,24)$. Distribusi frekuensi polimorfisme gen ACTN3 didapatkan berbeda pada setiap bangsa $(7,23,25)$. Hasil perhitungan frekuensi alel pada penelitian ini menunjukkan bahwa jumlah frekuensi alel X $(0,61)$ lebih banyak daripada alel $R$ $(0,39)$. Frekuensi genotif XX berbeda antar kelompok etnis, Asia 25\%, Kaukasia 18\%, Etiopia 11\%, Jamaika 3\% dan US Afrika-Amerika, dan penduduk Kenya; Nigeria yang memiliki genotife XX hanya sebesar $1 \%(7,25)$.

Pada hasil penelitian ini tidak ada daya ledak otot subjek 
dalam kategori rendah ataupun sangat rendah. Hal ini disebabkan karena sepak bola merupakan olah raga intermiten, sangat intensif dan kompleks sehingga peran kemampuan dasar, khususnya ledakan eksplosif, kekuatan, tendangan, melompat, berputar dan berlari menjadi komponen penting untuk menguasai bola $(1,3)$. Menjadi atlet sepakbola profesional dituntut memiliki daya ledak otot (power) diatas rata-rata karena akan banyak melakukan aktivitas yang menggunakan kekuatan eksplosif (26). Pemain bola professional melakukan 1.200-1.400 aktivitas yang berubah-ubah dan melakukan 150-250 serangan durasi pendek (1-4 detik) dengan intensitas tinggi (2). Pemain sepakbola tingkat profesional biasanya memiliki kemampuan fisik yang lebih baik dibandingkan dengan semi profesional atau amatir, mungkin disebabkan permintaan fisik yang lebih tinggi dalam pertandingan sepak bola professional (27). Kebiasaan hidup yang sehat pemain sepakbola mendukung tingginya daya ledak otot (3).

Latihan beban (weight training) dan pliometrik juga dilakukan untuk meningkatkan daya ledak (explosive power). Terdapat pengaruh latihan plyometric terhadap daya ledak otot $(28,29)$. Latihan beban dan pliometrik yang teratur mungkin membuat subjek dalam penelitian ini tidak menunjukkan daya ledak otot rendah dan daya ledak otot sangat rendah.

Hasil penelitian ini menunjukkan bahwa ada hubungan yang signifikan antara varian genotif (polimorfisme) ACTN3 dengan daya ledak otot. Penelitian ini didukung oleh Gineviciene yang menunjukkan bahwa ada hubungan signifikan antara polimorfisme gen ACTN-3 dengan explosive power di Lithuana (16). Cieszczyk (30) dan Druzhevskaya (10) menemukan adanya hubungan signifikan antara polimorfisme ACTN-3 dengan status atlet power di Polandia dan Rusia. Di sisi lain, Lucia (31) dalam penelitiannya menyatakan bahwa tidak ada perbedaan performa endurens terhadap varian genotif R577X pada atlet sepeda. Grenda (32) menemukan tidak ada ada hubungan antara polimorfisme ACTN-3 dengan aktivitas berenang sprint pada perenang di Polandia. Holdys (6) menunjukkan tidak ada hubungan signifikan antara polimorfisme R577X pada gen ACTN-3 dengan tingkat volume oksigen maksimum $\left(\mathrm{VO}_{2} \max \right)$, nilai $\mathrm{VO}_{2} \max$ cederung ditemukan lebih tingi pada individu dengan genotif XX dan RX (6).

Subjek dengan varian genotif RR dan RX memiliki daya ledak tinggi dan di atas rata-rata/rata-rata. Sementara subjek yang memiliki varian genotif XX hanya 2 orang memiliki daya ledak tinggi. Penelitian pada atlet sepak bola Brazil oleh Pimenta menyatakan bahwa atlet dengan genotif RR memiliki kemampuan lari jarak pendek dan lompat yang lebih cepat dan lebih tinggi dibandingkan dengan atlet dengan genotif XX dan RX (33). Sementara pada atlet sprint Olimpiade tidak ditemukan atlet yang memiliki varian genotif XX pada gen ACTN-3. Atlet elit sprint memiliki frekuensiRR yang lebih banyak dan atlet endurens memiliki frekuensi XX yang lebih tinggi. Kehadiran alel $\mathrm{R}$ mengindikasikan kapasitas performa kontraksi kekuatan otot yang besar (high power) baik dengan varian genotif RR maupun $R X$ dan di sisi lain alel $X$ mempengaruhi daya tahan (endurance) yang lebih baik dalam olahraga. Gen ACTN-3 dengan varian genotif RX memiliki alel R yang mengindikasikan kontraksi poweryang kuat dan memiliki alel $X$ yang memiliki daya tahan yang lama dan pasokan ATP yang stabil membuat serat oksidatif lebih resisten dari kelelahan. Keberhasilan daya ledak (power) seorang atlet bergantung pada proporsi serabut otot slow-twitch dibandingkan pada serabut otot fasttwitch terhadap otot yang dilatih (pada atlet sprinter; fasttwitch lebih mayoritas). Hal ini menunjukkan bahwa genotif RR merupakan salah satu marker genetik pada kemampuan anaerobik (fenotip daya ledak otot) sedangkan alel $X$ merupakan marker genetik untuk kemampuan aerobik (34,35).

Penelitian ini menunjukkan bahwa ada sebanyak 11 orang $(33,3 \%)$ subjek dengan varian genotif $X X$ yang memiliki daya ledak otot rata-rata/di atas rata-rata. Penelitian yang dilakukan oleh Gineviciene (16) pada elit atlet Lithuana $(n=193)$ menemukan bahwa varian genotif XX memiliki daya ledak otot yang lebih tinggi daripada varian genotif RR. Hal ini mungkin terjadi karena tidak adanya ACTN-3 (variasi genotif XX atau alel X) pada serat otot cepat dikompensasi oleh upregulasi ACTN2 dan enzim lain yang mengambil bagian dalam metabolisme anaerobik (16). ACTN-2 adalah satu-satunya isoform $\alpha$-aktinin sarkormer yang diekspresikan dalam otot pada keadaan defesiensi ACTN-3, peningkatan pensinyalan calcineurin adalah hasil dari pembebasan dari calcineurin dari pengaruh inhibisi calsarcin-2 sehingga mengaktifkan program serat otot lambat dan mengubah fenotif metabolik serat otot cepat (IIB) menjadi serat otot lambat $(7,14)$. Di sisi lain defesiensi ACTN-3 atau alel $\mathrm{X}$ (genotif $\mathrm{X}$ ) dikaitkan dengan penanda injuri setelah melakukan latihan eccentric dibandingkan dengan alel R (36). Garis Z menjadi kurang stabil selama kontraksi dengan peningkatan konsentrasi ACTN-2(37).

Pengujian kombinasi polimorfisme genetik lebih efektif seperti kombinasi gen ACTN-3 dan ACE atau beberapa kandidat kombinasi gen lainnya untuk melihat potensi bakat dalam olahraga (16). Kemampuan fisik manusia sangat kompleks, dipengaruhi oleh multifaktor keterlibatan fenotip berbagai gen (melibatkan beberapa gen), faktor lingkungan (interaksi gen dengan lingkungan)(8).

Berdasarkan hasil analisis statistik (uji Fisher) terdapat hubungan signifikan antara varian genotif ACTN-3 dengan daya ledak otot yang membuktikan bahwa alel $\mathrm{R}$ mengindikasikan kontraksi power yang kuat atau daya ledak otot baik pada varian genotif RR maupun RX. Genotif RX merupakan salah satu genotif kunci keberhasilan dalam sepakbola yang merupakan perpaduan antara aerob dan anaerob.

\section{UCAPAN TERIMAKASIH}

Penulis mengucapkan terima kasih kepada Dr.med.dr. Yahwardiah Siregar yang telah memberi izin menggunakan DNA yang tersimpan di Laboratorium Terpadu Fakultas Kedokteran Universitas Sumatera Utara dan yang mendanai pengumpulan sampel sel bukal sampai proses isolasi DNA, terima kasih kepada Roy Wilson, Binayanti dan Karin yang telah bekerja keras mengumpulkan sampel sel bukal dan melakukan isolasi DNA di Laboratorium Terpadu.

\section{DAFTAR PUSTAKA}

1. Lima LO and Rodrigues-de-Paula F. Muscular Power Training: A New Perspective in Physical Therapy

Approach of Parkinson's Disease. Revista Brasileira Fisioterapia. 2012; 16(2): 173-174.

2. Manzi V, Impellizzeri F, and Castagna C. Aerobic 
Fitness Ecological Validity in Elite Soccer Players: A Metabolic Power Approach. Journal of Strength and Conditioning Research. 2014; 28(4): 914-919.

3. Turner AN and Stewart PF. Strength and Conditioning for Soccer Players. Strength and Conditioning Journal. 2014; 36(4): 1-13.

4. Lloyd RS, Oliver JL, Faigenbaum AD, et al. Long-Term Athletic Development-Part 1: A Pathway for All Youth. Journal of Strength and Conditioning Research. 2015; 29(5): 1439-1450.

5. Ma F, Yang Y, Li X, et al. The Association of Sport Performance with ACE and ACTN3 Genetic Polymorphisms: A Systematic Review and MetaAnalysis. PLoS One. 2013; 8(1): 1-9.

6. Holdys J, J Kryścia, Stanisławski D, and Gronek P. Polymorphism of the $\alpha$-ACTN3 Gene in Individuals Practising Different. Biology of Sport. 2011; 28(2): 101-106.

7. Macarthur DG, Seto JT, Chan S, et al. An Actn3 Knockout Mouse Provides Mechanistic Insights into the Association Between $\alpha$-Actinin-3 Deficiency and Human Athletic Performance. Human Molecular Genetics. 2008; 17(8): 1076-1086.

8. Bray MS, Hagberg JM, Pérusse L, et al. The Human Gene Map for Performance and Health-Related Fitness Phenotypes: the 2006-2007 update. Medicine and Science in Sports and Exercise. 2009; 41(1): 35-73.

9. Berman $Y$ and North KN. A Gene for Speed: The Emerging Role of $\alpha$-Actinin-3 in Muscle Metabolism. Physiological Society. 2010;25:250-259.

10. Druzhevskaya AM, Ahmetov II, Astratenkova IV, and Rogozkin VA. Association of the ACTN3 R577X Polymorphism with Power Athlete Status in Russians. European Journal of Applied Physiology. 2008;103(6): 631-634.

11. Roth SM, Walsh S, Liu D, Metter EJ, Ferrucci L, and Hurley BF. The ACTN3 R577X Nonsense Allele is Under- represented in Elite-Level Strength Athletes. European Journal of Human Genetics. 2008; 16(3): 391-394.

12. Papadimitriou ID, Lucia A, Pitsiladis YP, et al. ACTN3 R577X and ACE I/D Gene Variants Influence Performance in Elite Sprinters: A Multi-Cohort Study. BMC Genomics. 2016; 17(1): 1-8.

13. Wajchenberg $M$, Luciano R, Araújo RC, Martins DE, Puertas EB, and Almeida SS. Polymorphism of the ACE Gene and the $\alpha$-Actinin-3 Gene in Adolescent Idiopathic Scoliosis. Acta Ortopedica Brasileira. 2013; 21(3): 170-174.

14. Quinlan KGR, Seto JT, Turner N, et al. $\alpha$-Actinin-3 Deficiency Results in reduced Glycogen Phosphorylase Activity and Altered Calcium Handling in Skeletal Muscle. Human Molecular Genetics. 2010; 19(7): 1335-1346.

15. Ahmetov II, Vinogradova OL, and Williams AG. Gene Polymorphisms and Fiber-Type Composition of Human Skeletal Muscle. International Journal of Sport Nutrition and Exercise Metabolism. 2012; 22(4): 292-303.
16. Gineviciene V, Pranculis A, Jakaitienè A, Milašius K, and Kučinskas V. Genetic Variation of the Human ACE and ACTN3 Genes and Their Association With Functional Muscle Properties in Lithuanian Elite Athletes. Medicina (Kaunas). 2011; 47(5): 284-290.

17. Veligekas P, Tsoukos A and Bogdanis GC. Determinants of Standing Long Jump Performance in 9-12 Year Old. Serbian Journal of Sport Science. 2012; 6(4): 147-155.

18. Gumilas NSA, Candrawati $\mathrm{S}$, dan Kusuma $\mathrm{MNH}$. Hubungan Polimorfisme Gen ACTN3 dengan Performa Otot pada Atlet UKM Sepak Bola Universitas Jenderal Soedirman. Jurnal Kedokteran Brawijaya. 2016; 29(1): 74-78.

19. Ambardini RL. Hubungan antara Polimorfisme R577X Gena ACTN3 dan Performa Fisik dalam Olahraga Atlet Indonesia. [Disertasi]. Universitas Gadjah Mada, Yogyakarta. 2015.

20. Candrawati S, Gumilas NSA, Kusuma $\mathrm{MNH}$, Adiningtyas PA, Sucipto MCR, dan Rahma SSA. Hubungan Polimorfisme Gen ACTN3 dengan Kelincahan, Daya Ledak, dan Kecepatan. Jurnal Kedokteran Brawijaya. 2017; 29(4): 329-334.

21. Ahmetov II, Druzhevskaya AM, Astratenkova IV, Popov DV, Vinogradova OL, and Rogozkin VA. The ACTN3 R577X Polymorphism in Russian Endurance Athletes. British Journal Sports Medicine. 2010; 44(9): 649-652.

22. Kothari ST, Chheda P, Chawla S, Chatterjee L, Chaudhry SK, and Das BR. ACTN3 R577X Polymorphism in Asian Indian Athletes. International Journal of Human Genetics. 2011; 11(3): 149-153.

23. Fattahi $Z$ and Najmabadi H. Prevalence of ACTN3 (the Athlete Gene) R577X Polymorphism in Iranian Population. Iranian Red Crescent Medical Journal. 2012; 14(10): 617-622.

24. Bernasovska J, Boronova I, Poracova J, et al. ACTN3 Genotype Association with Motoric Performance of Roma Children. International Journal of Social, Behavioral, Educational, Economic, Business, and Industrial Engineering. 2014; 8(11): 3735-3738.

25. Amorim CEG, Acuña-Alonzo $V$, Salzano FM, Bortolini MC, and Hünemeier T. Differing Evolutionary Histories of the ACTN3? R577X Polymorphism among the Major Human Geographic Groups. PLoS One. 2015; 10(2): 1-10.

26. Chan HCK, Fong DTP, Lee JWY, Yau QKC, Yung PSH, and Chan KM. Power and Endurance in Hong Kong Professional Football Players. Asia-Pacific Journal of Sports Medicine, Arthroscopy, Rehabilitation, and Technology. 2016; 5: 1-5.

27. Sporis G, Jukic I, Ostojic SM, and Mllanovic D. Fitness Profiling in Soccer: Physical and Physiologic Characteristics of Elite Players. Journal of Strength and Conditioning Research. 2009; 23(7): 1947-1953.

28. Makaruk $\mathrm{H}$ and Sacewicz T. Effects of Plyometric Training on Maximal Power Output and Jumping Ability. Human Movement. 2010; 11(1): 17-22.

29. Andrew DPS, Kovaleski JE, Heitman RJ, and Robinson TL. Effects of Three Modified Plyometric Depth Jumps 
and Periodized Weight Training on Lower Extremity Power. The Sport Journal. 2010; 36: 1-13.

30. Cięszczyk P, Eider J, Ostanek M, et al. Association of the ACTN3 R577X Polymorphism in Polish PowerOrientated Athletes. Journal of Human Kinetics. 2011; 28: 55-61.

31. Lucia A, Gómez-Gallego F, Santiago C, et al. ACTN3 Genotype in Professional Endurance Cyclists. International Journal of Sport Medicine. 2016; 27(11): 880-884.

32. Grenda A, Leońska-Duniec A, Kaczmarczyk M, et al. Interaction between ACE I/D and ACTN3 R557X Polymorphisms in Polish Competitive Swimmers. Journal of Human Kinetics. 2014; 42: 127-136.

33. Pimenta EM, Coelho DB, Veneroso, CE, et al. Effect of ACTN3 Gene on Strength and Endurance in Soccer. The Journal of Strength and Condition Research.
2013; 27(12): 3286-3292.

34. Ahmetov II, Donnikov AE, and Trofimov DY. ACTN3 Genotype is Associated with Testosterone Levels of Athletes. Biology of Sport. 2014; 31(2): 105-108.

35. Ahmetov II, Gavrilov DN, Astratenkova IV, et al. The association of ACE, ACTN3 and PPARA Gene Variants with Strength Phenotypes in Middle School-Age Children. The Journal of Physiological Science. 2013;63(1):79-85.

36. Vincent $\mathrm{B}$, Windelinckx $\mathrm{A}$, Nielens $\mathrm{H}$, et al. Protective Role of $\alpha$-Actinin-3 in the Response to an Acute Eccentric Exercise Bout. Journal of Applied Physiology. 2010; 109(2): 564-573.

37. Seto JT, Lek M, Quinlan KG, et al. Deficiency of $\alpha$ Actinin-3 is Associated with Increased Susceptibility to Contraction-Induced Damage and Skeletal Muscle Remodeling. Human Molecular Genetics. 2011; 20(15): 2914-2927. 